\title{
Importance-Performance Analysis Sebagai Alat Evaluasi Kualitas Pelayanan Pendidikan Tinggi (Studi Kasus FIP Universitas Pendidikan Ganesha)
}

\author{
Gusti Ngurah Sastra Agustika1, ${ }^{1}{ }^{*}$, I G. A. Ayu Wulandari ${ }^{2}$, I Nyoman Laba Jayanta ${ }^{3}$ \\ 1,2,3Jurusan Pendidikan Guru Sekolah Dasar, Universitas Pendidikan Ganesha
}

\begin{abstract}
Abstrak
Keberhasilan lembaga penyelenggara pendidikan sangat ditentukan oleh kualitas pelayanan yang dapat diukur melalui kepuasan mahasiswa sebagai pelanggan jasa pendidikan. Penelitian ini bertujuan untuk 1) mengukur tingkat kepuasan mahasiswa terhadap pelayanan Fakultas Ilmu Pendidikan Universitas Pendidikan Ganesha, 2) mengetahui faktor dan variabel apa yang harus harus ditingkatkan untuk memenuhi kepuasan mahasiswa, 3) mengetahui faktor dan variabel apa yang harus tetap dipertahankan untuk memenuhi kepuasan mahasiswa, 4) apakah layanan yang diterima mahasiswa sudah sesuai dengan yang diharapkan mahasiswa. Data penelitian diperoleh dengan menggunakan kuesioner sebagai alat pengumpul data. Dimensi yang digunakan menyusun istrumen merupakan dimensi-dimensi yang menentukan kualitas pelayanan yang terdiri dari 5 dimensi yaitu: 1) bukti langsung (tangible), 2) keandalan (Reability), 3) daya tanggap (Responsiveness), 4) jaminan (Assurance), dan 5) Empati (Emphaty). Jumlah responden yang digunakan sebagai sampel berjumlah 321 responden yang diambil secara proporsional berdasarkan jumlah mahasiswa setiap jurusan. Teknik analisis yang digunakan adalah statistika deskriptif untuk mengetahui tingkat kepuasan mahasiswa, dilanjutkan dengan importance-performance analysis untuk mengetahui tingkat kepentingan dan kepuasan mahasiswa. Dari hasil penelitian diperoleh bahwa tingkat kepuasan mahasiswa terhadap pelayanan akademik secara umum adalah cukup baik dengan persentase tingkat kepuasan sebesar 68,97\%. Hasil Importance-Performance Analysis menunjukkan terdapat 6 indikator pelayanan yang harus mendapat prioritas peningkatan dan 3 indikator pelayanan yang harus dipertahankan untuk memenuhi kepuasan mahasiswa.
\end{abstract}

\author{
Keywords: \\ Kepuasan; \\ Importance Performance \\ Analysis; \\ Pelayanan Akademik
}

\section{Pendahuluan}

Perguruan tinggi sebagai sebuah lembaga pendidikan formal tertinggi memiliki tanggung jawab untuk mencetak sumber daya manusia yang bermutu, dan siap menghadapi dunia kerja. Ketatnya persaingan dunia kerja membuat masyarakat semakin cermat dalam menentukan perguruan tinggi untuk mempersiapkan diri memasuki dunia kerja. Keadaan ini menghadapkan persaingan antar perguruan tinggi semakin kompetitif. Persaingan antar perguruan tinggi yang semakin kompetitif menuntut lembaga perguruan tinggi untuk selalu berbenah meningkatkan mutu pendidikan sehingga dapat serta unggul dalam persaingan tersebut. Banyak faktor yang menjadi penilaian masyarakat dalam menentukan pilihan sebuah perguruan tinggi yang bermutu, salah satu diantaranya adalah kualitas layanan memenuhi kepuasan dan kebutuhan belajar mahasiswa. Karena dengan adanya pelayanan yang baik terhadap mahasiswa maka akan dapat menggambarkan mutu perguruan tinggi di mata mahasiswa. Saat ini, kualitas layanan dipandang sebagai salah satu cara untuk mencapai keunggulan kompetitif karena keberhasilan suatu perguruan tinggi sangat ditentukan oleh mutu layanan yang diberikan, dimana layanan yang bermutu dapat diindentifikasi dari kepuasan pelanggan, dalam hal ini adalah kepuasan mahasiswa.

Pengukuran mutu layanan sangat penting dalam menyediakan layanan yang lebih baik. Oleh karena itu, mutu layanan dimulai dari kebutuhan mahasiswa akan pelayanan dan berakhir pada persepsi mahasiswa terhadap mutu layanan dan bukan persepsi lembaga penyedia layanan. Perbandingan antara harapan mahasiswa dengan kinerja yang diperoleh dalam penyelenggaraan akademik akan menunjukkan tingkat kepuasan mahasiswa terhadap pelayanan yang diperoleh. Kepuasan menurut Kotler (2000) 
adalah perasaan senang atau kecewa seseorang yang berasal dari perbandingan antara kesannya terhadap kinerja suatu produk dengan harapannya. Sedangkan menurut Sugito (2005) kepuasan pelanggan adalah suatu keadaan terpenuhinya keinginan, harapan dan kebutuhan pelanggan. Berdasarkan pendapat tesebut dapat disimpulkan bahwa kepuasan merupakan suatu keadaan terpenuhinya keinginan, harapan dan kebutuhan mahasiswa yang berasal dari perbandingan antara kesannya terhadap pelayanan dengan harapannya. Bila pelayanan yang diberikan dapat memenuhi keinginan, harapan, dan kebutuhan pelanggan, dinilai pelayanan itu memuaskan.

Keberhasilan suatu lembaga perguruan tinggi sangat ditentukan oleh kualitas pelayanan yang diberikan. Menurut Cravens (Rahmawati, 2014) menyatakan bahwa untuk mencapai tingkat kepuasan yang tinggi, diperlukan adanya pemahaman tentang apa yang diinginkan oleh konsumen yang ada dalam lembaga untuk memenuhi kebutuhan konsumen yang bersangkutan. Hal ini menunjukkan bahwa kepuasan mahasiswa berawal dari pemahaman tentang apa yang diinginkan oleh mahasiswa. Menurut Evans dan Berman (Rahmawati, 2014) bahwa penyedia jasa pendidikan bersifat nirlaba. Walaupun demikian sebagai suatu organisasi yang berorientasi nirlaba, lembaga penyedia jasa pendidikan tidak berarti dapat mengabaikan persaingan dan pemasaran. Persaingan antar lembaga perguruan tinggi akan terus mengubah lingkungan pendidikan tinggi menjadi semakin berkembang sehingga akan dapat menghasilkan lulusan yang semakin berkualitas.

Fakultas Ilmu Pendidikan Universitas Pendidikan Ganesha (FIP UNDIKSHA) merupakan salah satu unit kerja di lingkungan Undiksha yang menyediakan layanan dibidang pendidikan harus menerapkan konsep mengutamakan kepuasan mahasiswa sebagai pelanggan dengan memberikan pelayanan terbaik. Kepuasan mahasiswa akan tercapai apabila kualitas layanan yang diberikan sesuai kebutuhannya, sehingga perguruan tinggi harus menjadikan peningkatan mutu pelayanan pendidikan sebagai tujuan yang mendasar. Lord Kelvin (Evangelos, 2010) menyatakan bahwa "if you cannot measure something, you cannot understand it". Sehingga pengukuran kepuasan mahasiswa merupakan salah satu program penting yang harus dilakukan untuk memberikan kerangka perumusan kebijakan. Berdasarkan hal tersebut, maka kepuasan mahasiswa harus diukur. Kepuasan mahasiswa dapat diukur melalui dimensi atau aspek-aspek dalam kualitas pelayanan yang kemudian disederhanakan menjadi variabel-variabel. Untuk dapat melihat bagaimana kinerja dan kualitas setiap variabel maka digunakan importance performance analysis (IPA). IPA merupakan salah satu alat terpopular saat ini yang digunakan oleh peneliti yang memiliki konsep berfokus pada model multi variabel (multi-attribute models). Teknik IPA dapat mengidentifikasi kekuatan dan kelemahan dari variabel yang digunakan oleh pelanggan dalam menentukan pilihan ke dalam 2 kriteria. Kriteri pertama menunjukkan tingkat kepentingan suatu variabel dan kriteria kedua menunjukkan tingkat kinerja. Sehingga dengan menggunakan IPA maka dapat diketahui variabel apa saja yang sudah baik dan harus dipertahankan serta variabel apa saja yang masih kurang dan perlu untuk ditingkatkan. Interpretasi grafik IPA dibagi menjadi empat buah kuadran berdasarkan hasil pengukuran importance-performace seperti terlihat pada Gambar 1.

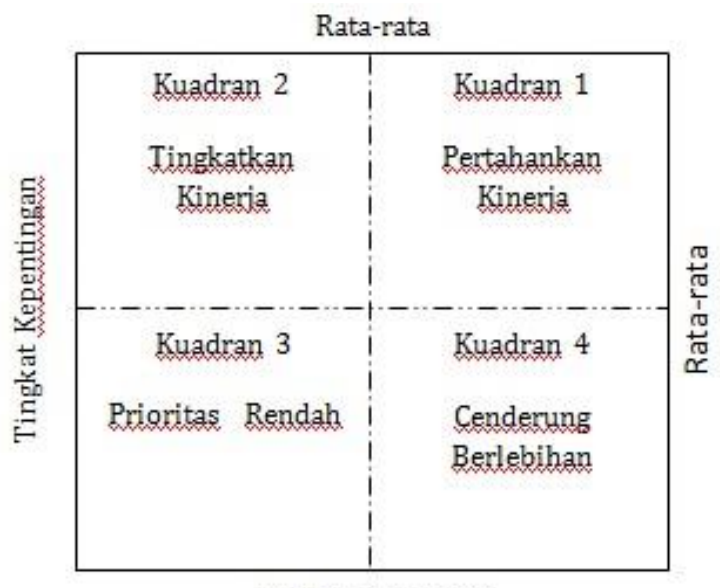

Tingkat Kepuasan

Gambar 1. Pembagian Kuadran IPA 


\section{Metode}

Pendekatan yang digunakan dalam penelitian ini adalah penelitian dasar (fundamental research). Penelitian dasar dipilih sebagai pendekatan yang digunakan dalam penelitian ini didasari oleh dua hal, yaitu: 1) penelitian ini bermaksud untuk menemukan faktor atau variabel apa saja yang dianggap penting oleh mahasiswa dan juga untuk menemukan faktor atau variabel apa saja yang perlu ditingkatkan untuk memenuhi kepuasan mahasiswa. 2) penelitian ini juga bermaksud untuk mengetahui apakah kualitas pelayanan yang diberikan sudah sesuai dengan apa yang diharapkan oleh mahasiswa.

Penelitian ini menggunakan kuesioner sebagai alat bantu pengumpulan data kepuasan mahasiswa sebagai penerima pelayanan. Kuesioner disusun berdasarkan tujuan survei terhadap tingkat kepuasan mahasiswa. Bentuk jawaban pertanyaan dari setiap unsur pelayanan secara umum mencerminkan tingkat kepuasan dan harapan mahasiswa, yaitu dari yang tidak memuaskan sampai dengan sangat memuaskan dan untuk harapan mahasiswa dari yang tidak penting sampai dengan sangat penting. Untuk kategori tidak memuaskan/tidak penting diberi nilai pesepsi 1 , kurang memuaskan/kurang penting diberi nilai persepsi 2, cukup memuaskan /cukup penting diberi nilai persepsi 3, memuaskan /penting diberi nilai persepsi 4, sangat memuaskan/sangat penting diberi nilai persepsi 5.

Populasi dalam penelitian ini adalah seluruh mahasiswa FIP Undiksha yang masih aktif terdaftar pada tahun ajaran 2015/2016 yang berjumlah 1683 mahasiswa. pengambilan sampel pada penelitian ini dilakukan dengan menggunakan teknik pengambilan sampel acak secara proporsional (proportional random sampling) berdasarkan jumlah mahasiswa setiap jurusan dan kategori berdasarkan jenis kelamin. Dengan menggunakan rumus slovin diperoleh jumlah sampel sebanyak 321 responden.

\section{Hasil dan Pembahasan}

Jumlah responden yang digunakan sebagai sampel pada penelitian ini berjumlah sebanyak 321 mahasiswa. Responden yang ikut berpartisipasi merupakan mahasiswa FIP pada semester 4, yang terdiri dari 4 jurusan, yaitu jurusan PGSD sebesar 75,08\%, jurusan PAUD sebesar 11,53\%, jurusan BK sebesar $7,79 \%$, dan jurusan TP sebesar 5,61\%. Jumlah seluruh responden Laki-laki sebesar 30,84\% dan responden Perempuan sebesar 69,16\%.

Ringkasan data hasil pengisian kuesioner oleh responden yang berjumlah 321 mahasiswa disajikan disajikan pada Tabel 1 berikut:

Tabel 1. Ringkasan data

\begin{tabular}{|c|c|c|c|c|c|}
\hline \multirow[t]{2}{*}{ No } & \multirow[t]{2}{*}{ Aspek/Indikator } & \multicolumn{2}{|c|}{$\begin{array}{c}\text { Kinerja } \\
\text { (Kenyataan) }\end{array}$} & \multicolumn{2}{|c|}{$\begin{array}{c}\text { Kepentingan } \\
\text { (harapan) }\end{array}$} \\
\hline & & $\mathbf{M}$ & $\mathbf{s}$ & $\mathbf{M}$ & $\mathbf{s}$ \\
\hline A & Bukti langsung & 3,26 & 0,76 & 4,79 & 0,45 \\
\hline A1 & Fasilitas fisik/Sarana prasarana & 3,29 & 0,71 & 4,8 & 0,44 \\
\hline A2 & Sistem Komputerisasi Akademik & 3,21 & 0,79 & 4,8 & 0,45 \\
\hline A3 & Penampilan staf pegawai dan dosen & 3,29 & 0,78 & 4,74 & 0,48 \\
\hline $\mathrm{A} 4$ & $\begin{array}{l}\text { Perlengkapan dan peralatan } \\
\text { pembelajaran }\end{array}$ & 3,25 & 0,76 & 4,81 & 0,44 \\
\hline B & Keandalan & 3,52 & 0,75 & 4,80 & 0,46 \\
\hline B1 & Ketepatan waktu kuliah & 3,17 & 0,73 & 4,77 & 0,46 \\
\hline B2 & Kesesuaian pelaksanaan jadwal kuliah & 3,39 & 0,71 & 4,83 & 0,41 \\
\hline B3 & $\begin{array}{l}\text { Ketepatan materi dalam proses belajar } \\
\text { mengajar }\end{array}$ & 3,59 & 0,72 & 4,88 & 0,33 \\
\hline B4 & Ketepatan waktu pelayanan & 3,64 & 0,72 & 4,75 & 0,49 \\
\hline B5 & Pelayanan yang ramah & 3,74 & 0,72 & 4,77 & 0,46 \\
\hline $\mathbf{C}$ & Daya Tanggap & 3,4 & 0,74 & 4,77 & 0,47 \\
\hline $\mathrm{C} 1$ & $\begin{array}{l}\text { Kesediaan dosen membantu mahasiswa } \\
\text { dalam mengatasi kesulitannya }\end{array}$ & 3,46 & 0,77 & 4,79 & 0,44 \\
\hline $\mathrm{C} 2$ & $\begin{array}{l}\text { Kesediaan pegawai membantu } \\
\text { mahasiswa dalam mengatasi } \\
\text { kesulitannya }\end{array}$ & 3,15 & 0,7 & 4,85 & 0,4 \\
\hline $\mathrm{C} 3$ & Kesediaan dosen menyediakan waktu & 3,34 & 0,68 & 4,76 & 0,45 \\
\hline
\end{tabular}




\begin{tabular}{|c|c|c|c|c|c|}
\hline C4 & $\begin{array}{l}\text { untuk berkonsultasi di luar jam } \\
\text { mengajar } \\
\text { Pegawai cepat dan tanggap dalam } \\
\text { menyelesaikan setiap keluhan } \\
\text { mahasiswa }\end{array}$ & 3,65 & 0,71 & 4,67 & 0,56 \\
\hline D & Jaminan & 3,65 & 0,69 & 4,75 & 0,48 \\
\hline D1 & $\begin{array}{l}\text { Pemahaman dan wawasan dosen dalam } \\
\text { melaksanakan proses pembelajaran }\end{array}$ & 3,77 & 0,71 & 4,71 & 0,54 \\
\hline D2 & $\begin{array}{l}\text { Pengetahuan dan kecakapan pegawai } \\
\text { terhadap layanan yang tepat }\end{array}$ & 3,56 & 0,7 & 4,81 & 0,42 \\
\hline D3 & $\begin{array}{l}\text { Melakukan komunikasi yang efektif } \\
\text { dengan mahasiswa }\end{array}$ & 3,63 & 0,63 & 4,74 & 0,46 \\
\hline $\mathbf{E}$ & Empati & 3,66 & 0,69 & 4,8 & 0,42 \\
\hline E1 & $\begin{array}{l}\text { Keramahan dan perhatian dosen dalam } \\
\text { berinteraksi dengan mahasiswa }\end{array}$ & 3,57 & 0,7 & 4,76 & 0,46 \\
\hline E2 & $\begin{array}{l}\text { Keramahan dan perhatian pegawai } \\
\text { dalam berinteraksi dengan mahasiswa }\end{array}$ & 3,75 & 0,66 & 4,84 & 0,37 \\
\hline
\end{tabular}

Hasil analisis data menggambarkan tingkat kepuasan mahasiswa terhadap pelayanan akademik secara umum adalah baik dengan persentase tingkat kepuasan sebesar 68,97\%. Hasil ini diperoleh dengan memberikan pernyataan yang disusun berdasarkan 18 indikator. Dari hasil analisis data diketahui persentase responden berdasarkan tingkat kepuasan yang disajikan pada Tabel 2.

Tabel 2. Persentase Tingkat kepuasan responden

\begin{tabular}{l|c}
\hline \multicolumn{1}{c|}{ Tingkat Kepuasan } & Persentase (\%) \\
\hline Sangat baik & 1,87 \\
Baik & 20,9 \\
Cukup baik & 71 \\
Kurang baik & 6,23 \\
Tidak baik & 0,00 \\
\hline
\end{tabular}

Indikator pelayanan yang harus ditingkatkan dan dipertahankan untuk memenuhi kepuasan mahasiswa diperoleh dengan metode analisis IPA. Dari hasil analisis data dengan metode IPA diperoleh pembagian kuadran masing-masing layanan yang dapat di plot seperti pada Gambar 2.

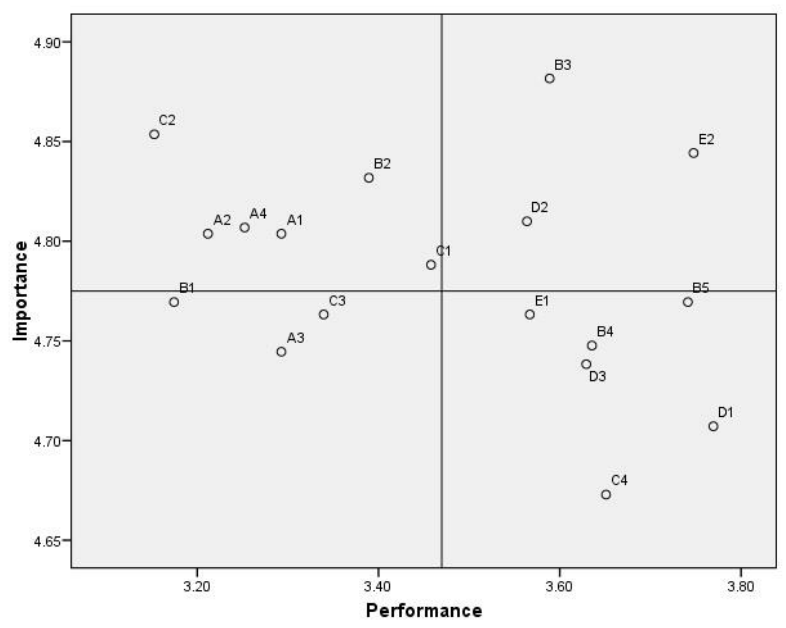

Gambar 2. Pembagian Kuadran Indikator Pelayanan Akademik 
Berdasarkan Gambar 2 dapat diketahui posisi kuadran setiap indikator pelayanan yang dapat disajikan seperti pada Tabel 3.

Tabel 3 Ringkasan Posisi Indikator Pelayanan Dalam Kuadran

\begin{tabular}{|c|l|}
\hline Kuadran & Indikator Pelayanan \\
\hline \multirow{4}{*}{ I } & Ketepatan materi dalam proses belajar mengajar (B3) \\
\cline { 2 - 3 } & Pengetahuan dan kecakapan pegawai terhadap layanan yang tepat (D2) \\
\cline { 2 - 3 } & Keramahan dan perhatian pegawai dalam berinteraksi dengan mahasiswa (E2) \\
\hline \multirow{5}{*}{ II } & Fasilitas fisik/Sarana prasarana (A1) \\
\cline { 2 - 3 } & Sistem Komputerisasi Akademik (A2) \\
\cline { 2 - 3 } & Perlengkapan dan peralatan pembelajaran (A4) \\
\cline { 2 - 3 } & Kesesuaian pelaksanaan jadwal kuliah (B2) \\
\cline { 2 - 3 } & Kesediaan dosen membantu mahasiswa dalam mengatasi kesulitannya (C1) \\
\hline \multirow{5}{*}{ III } & Pesediaan pegawai membantu mahasiswa dalam mengatasi kesulitannya (C2) \\
\cline { 2 - 3 } & Ketepatan waktu kuliah (B1) \\
\cline { 2 - 3 } & Kesediaan dosen menyediakan waktu untuk berkonsultasi di luar jam mengajar (C3) \\
\hline \multirow{5}{*}{ IV } & Ketepatan waktu pelayanan (B4) \\
\cline { 2 - 3 } & Pelayanan yang ramah (B5) \\
\cline { 2 - 3 } & Pegawai cepat dan tanggap dalam menyelesaikan setiap keluhan mahasiswa (C4) \\
\cline { 2 - 3 } & Pemahaman dan wawasan dosen dalam melaksanakan proses pembelajaran (D1) \\
\cline { 2 - 3 } & Melakukan komunikasi yang efektif dengan mahasiswa (D3) \\
\cline { 2 - 3 } & Keramahan dan perhatian dosen dalam berinteraksi dengan mahasiswa (E1) \\
\hline
\end{tabular}

Berdasarkan Tabel 3 maka dapat diketahui indikator pelayanan yang harus dipertahankan adalah indikator yang posisinya berada pada kuadran I dan indikator pelayanan yang harus ditingkatkan adalah indikator yang posisinya berada pada kuadran II.

\section{Simpulan dan Saran}

Hasil pengukuran kepuasan mahasiswa terhadap pelayanan akademik diperoleh tingkat kepuasan mahasiswa terhadap pelayanan akademik adalah baik dengan tingkat kepuasan sebesar 68,97\%. Kualitas pelayanan terbaik yang dirasakan oleh mahasiswa adalah pada pemahaman dan wawasan dosen dalam melaksanakan proses pembelajaran. Indikator pelayanan akademik yang harus ditingkatkan untuk memenuhi kepuasan mahasiswa adalah fasilitas fisik/sarana prasarana, sistem komputerisasi akademik, perlengkapan dan peralatan pembelajaran, kesesuaian pelaksanaan jadwal kuliah, dan kesediaan dosen serta pegawai membantu mahasiswa dalam mengatasi kesulitan.

Berdasarkan simpulan yang diperoleh, rekomendasi yang dapat diberikan adalah perlu dilaksanakan perbaikan fasilitas atau pelayanan yang mengacu kepada pemenuhan kebutuhan akademik mahasiswa serta lembaga perlu melakukan identifikasi mengenai kebutuhan riil yang diperlukan mahasiswa sehingga diperoleh kesesuaian antara kebutuhan mahasiswa dan fasilitas yang disiapkan oleh lembaga.

\section{References}

Francisco J. Miranda, Antonio Chamorro, Luis R. Murillo, Juan Vega. 2010. An Importance-Perfomance Analysis of Primary Health Care Services: Managers Vs Patients Perceptions. Journal Service Science \& Management. Vol 3 227-234

Handayani, R, Yermias T. K., \& Ratminto. (2003). Analisis kepuasan pemakai terhadap pelayanan perpustakaan nasional provinsi daerah istimewa Yogyakarta. Sosiosains, vol 17(2), April 2003. Pasca Sarjana Fisipol UGM, Yogyakarta.

Kotler, P. 2000. Marketing Management, Millenium Edition. New Jersey: Prentice-Hall International, Inc.

Oliver, Richard L. 2010. Satisfaction : A Behavioral Perspective on the consumer. Routledge: Taylor \& Francis Group. New York

Rahmawati, M. 2014. Analisis Tingkat Kepuasan Mahasiswa Terhadap Pelayanan Kampus. ASSETS, Volume 4 (2). Desember 2014: 225-234 
Sugito, H. 2005. Mengukur Kepuasan Pelanggan. (On-line). www.eprints.qut.du/achieve/0003941/01/3491/pdf. Diakses 7 Maret 2016

Srinadi, I Gusti Ayu Made dan Desak Putu Eka Nilakusmawati. 2008. Faktor-faktor penentu kepuasan mahasiswa terhadap pelayanan fakultas sebagai lembaga pendidikan (Studi kasus FMIPA Universitas Udayana). Cakrawala Pendidikan Tahun XXVII No. 3. Denpasar

Sangadji, Mamang,dkk. 2013. Perilaku Konsumen. Yogyakarta: Andi Yogyakarta

Sugiyono. 2010. Metode Penelitian Kuantitatif Kualitatif \& RND. Alfabeta. Bandung 